\title{
ASSESSMENT OF INVESTMENT PROJECT RISKS IN AVIATION
}
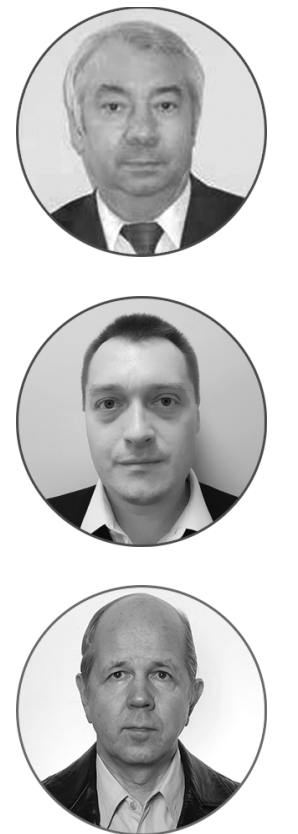

\section{Article history:}

Received 30 January 2018

Received in revised form

21 February 2018

Accepted 16 March 2018

Translated 25 May 2018

Available online 27 June 2018

JEL classification: C15, C51, D85, L53, M21

Keywords: productive potential, enterprise, aviation industry, investment project, risk

\author{
Aleksandr M. BAT'KOVSKII \\ Moscow Aviation Institute (National Research University) (MAl), Moscow, Russian Federation \\ batkovsky@yandex.ru \\ Corresponding author
}

\section{Vladislav V. KLOCHKOV}

National Research Center Zhukovsky Institute, Moscow, Russian Federation vlad_klochkov@mail.ru

\section{Evgenii Yu. KHRUSTALEV}

Central Economics and Mathematics Institute (CEMI), Russian Academy of Sciences, Moscow, Russian Federation stalev777@yandex.ru

\begin{abstract}
Importance Investment projects for developing the productive potential of aviation enterprises have a protracted period of equity divestment. Throughout the period, the projected conditions may change. To adapt to such unpredictable developments, enterprises have to incur significant financial costs, thus causing unrecoverable losses. Therefore, many projects at the investment stage are exposed to material risk.

Objectives We devise a new approach to evaluating whether the productive potential of the Russian aviation industry is effectively developed. Throughout the implementation period, there come out different estimates of the demand, cost, and new technologies. Managing the implementation of protracted investment projects requires a toolkit for applying the real options approach.

Methods The research relies upon methods of logic and statistical analysis, and mathematical modeling in economics.

Results We propose a new classification of possible changes in the investment project environment. We analyzed losses by project implementation scenario at different stages. The research also considers the specifics of the aviation industry and analyzes how the technological level of production influences respective risks.

Conclusions and Relevance We assessed the effectiveness of the productive potential development in the Russian aviation industry. It would be reasonable to consider our estimates to analyze the effectiveness of adaptive management of protracted investment projects for the productive potential development. The estimates may help identify the most material risks at different stages of such projects. We also provide our recommendations for optimizing the management of such risks.
\end{abstract}

The editor-in-charge of this article was Irina M. Vechkanova Authorized translation by Irina M. Vechkanova 
Projects for productive capacity construction (rehabilitation) account for the main part of investment projects aviation enterprises implement. They usually take a long period of time, which may see some changes influencing the cost effectiveness of the constructed capacity. Notwithstanding this fact, while implementing investing projects, aviation enterprises and their regulators, first of all, control whether expenditures have been reasonably incurred, whereas they should better analyze their decisions on allocation of funding and its purposes.

The existing governance system for aviation enterprises fails to provide for evaluation of project marketing prospects in line with changed in the market situation, technology, foreign exchange rates, etc. This seriously affects the effectiveness of corporate potential development management. Due to the above circumstances, enterprises incur losses in an unstable business environment, when developing the pool of their tangible resources. It is reasonable to apply methodological approaches and tools offered by the real options theory to address the issues as part of corporate potential management [1, 2].

As set forth in the National Program of the Russian Federation, Development of the Aviation Industry for 2013-2025, the aviation industry experiences a large scale retrofitting process that requires substantial capital expenditures. Considering limited equity of enterprises, national budget (which happened to entail the adjustment of the national program and sequestration of planned investments), weakening Russian ruble, which additionally causes a reduction in procurement of expensive production equipment imported into Russia, it is sensible to focus on the quality in substantiating investment decisions and analyzing inherent risks.

Some researches [3] justify that discrete project finance is reasonable, notwithstanding high risk exposure. Under such financial schemes, funds are earmarked for certain phases of high risk projects after the previous phase is accomplished with reference to forecasts of

\footnotetext{
${ }^{\dagger}$ For the source article, please refer to: Батьковский A.M., Клочков В.В., Хрусталёв Е.Ю. Оценка рисков осуществления инвестиционных проектов в авиационной промышленности. Национальные интересы: приоритеты и безопасность. 2018. Т. 14. № 5. C. 941-954.

URL: https://doi.org/10.24891/ni.14.5.941
}

the future market conditions for such protracted projects [4]. Some Russian and foreign researchers [58] review what specifically distinguishes the evaluation of investment projects implying some elements of options. Project risks are different throughout project phases, indeed [9].

Analyzing whether aviation enterprises' potential development is managed effectively, it is necessary to consider their distinctive features. In this research we do not refer to models and formulas for real options assessment that arise from the flexible management of investment projects. In the mean time, drawing upon quantitative assessments of risks arising at different phases of projects, we can build such models on assumptions about properties of random processes transforming the project environment.

Should the planned product mix be modified, productive capacity needs to be adapted to the quantity of products. Likewise if requirements to the future products are adjusted and predicted prices for necessary resources are specified, productive capacity shall be reconfigured in terms of quality ${ }^{1}[10]$.

Investment projects for productive capacity construction (rehabilitation) in aviation contain all typical phases of their performance, i.e. Research and Development (R\&D), construction and mounting, testing and commissioning. It is advisable to combine all the phases to reduce the lead time of investment projects. However, the existing fiscal rules often prohibit to do so since financial control of expenditures shall be tightened. As a result, stringent control often has side effects. For example, losses since phases of investment projects are impossible to combine[11].

Capital expenditures and technological structure, which differs through segments, determine the cost of typical phases of investment projects and its respective percentage. For example, nowadays expenses for equipment account for $80-90 \%$ and $60-70 \%$ in aircraft engine manufacturing and aircraft engineering respectively. However, percentage of equipment expenditures has been increasing for recent years in aircraft engineering as manual operations become more and more automated.

\footnotetext{
${ }^{1}$ Cedric J. A Quantitative Real Options Method for Aviation Technology Decision-Making in the Presence of Uncertainty. Georgia Institute of Technology, 2016. URL: http://hdl.handle.net/1853/54452
} 
In the aviation industry of various countries, the technological structure of investment consists of a different percentage of buildings and facilities due to climate and other factors. For example, the percentage is lower in the USA than Russia. However, as the Russian aviation industry is technologically retrofitted and available resources grow, equipment expenditures increase as well.

If parameters of the investment project for productive capacity construction change, additional costs shall be incurred to adapt it to the new parameters. Analyzing the changes, it is reasonable to consider two phases of the project implementation that absorb greater portions of investment:

\section{1) construction and mounting;}

2) procurement and installation of equipment, testing and commissioning.

The total length of these phases can be expressed as $\tau_{R \& D+C o n s t \& \text { mount }}$ (this summand equals the sum of the duration of R\&D and Construction \& Mounting: $\tau_{R \& D+\text { Const\&Mount }}=\tau_{R \& D}+\tau_{\text {Constr\&Mount }}$ ) and $\tau_{\text {Equip+Test\&Commis }}$ (resulting from the duration of procurement and installation of equipment and commissioning: $\tau_{\text {Equip }+ \text { Test\&Commis }}=\tau_{\text {Equip }}+\tau_{\text {Test\&Commis }}$ ). We denote the volume of investment as $I_{R \& D+C o n s t \& M o u n t}$ and $I_{\text {Equip+Test\&commis. }}$ In most segments of the aviation industry, they correlate in the following manner: $I_{\text {Equip+Test\&Commis }}>I_{\text {R\&D+Const\&Mount }}$.

There is no definite correlation between the duration of the above phases in all investment projects for productive capacity constructions in aviation since it depends on many aspects. However, in most cases the following relation is true: $\tau_{R \& D+C o n s t \& M o u n t}>\tau_{\text {Equip+Test\&Commis }}$. Total indicators of the project value and its duration equal as follows: $\tau=\tau_{\text {R\&D+Const\&Mount }}+\tau_{\text {Equip }+ \text { Test\&Commisi }}$ $I=I_{\text {Equip }+ \text { Test\&Commis }}+I_{\text {R\&D+Const\&Mount }}$.

To simplify the analysis, we assume that work at each phase of an investment project is financed evenly. Then we can depict how the accumulated amount of investment $I_{\Sigma}(t)$ has been changing throughout the investment project period (Fig. 1).

We examine what if the aviation enterprise changes its plans while implementing the investment project at the phase of construction and mounting, including testing and commissioning. At this phase, buildings, facilities and engineering infrastructure are constructed or rehabilitated. That is why, if the product mix is to be altered, this will not have a strong effect on characteristics of fixed assets in progress (their passive part). If production technology is to be altered, these modification will require to specify requirements to various characteristics of production, i.e. environmental, sanitary, power engineering, etc. Characteristics of the passive part of fixed assets are most influenced by changes in planned volume of production. It is caused by low liquidity of buildings and facilities at aviation enterprises. When the planned volume of production is reduced, capital losses may arise as much as 10-30 percent of the project value.

At the following consolidated phase, when necessary procurement takes place and purchased equipment is mounted and configured, the said changes in various project parameters have an absolutely different effect. Considering the versatile and innovative nature of modern equipment, financial injections may not be significantly increased to alter the product mix at the former technological level, while keeping the general type of production, in comparison with the initial costs incurred to purchase, install and configure the equipment. Hence investment of a multiproduct enterprise in purchase, installation and configuration of equipment can be classified as follows ${ }^{2}$ :

- general (integral) investment intended to purchase, install and configure versatile equipment, new software and information systems, train, retrain and ensure professional advancement of managing and attending personnel, develop and manufacture structural components with the predetermined type and quality of various final products, etc;

- special-purpose (special) investment intended to manufacture or acquire unique facilities for producing predetermined types and dimensions of products, and elaborating and improving the software and information framework for the same purposes.

As we note above, versatile, up-to-date, highly automated innovative equipment for production make many elements of different aircraft specimens technologically convergent. The degree of technological convergence substantially increases. It means that integral investment significantly rises by 50 percent in

\footnotetext{
${ }^{2}$ Klochkov V.V. [Evaluating the economic viability of integration of aircraft engine construction]. Polet = Flight, 2006, no. 7, pp. 28-33. (In Russ.)
} 
most segments and aviation enterprises. Due to the same reason, even dramatic and continuous changes in the product mix will not require considerable special-purpose investment, which will not exceed 20 percent of the total value of the investment project.

If the technological level of production or applicable technology changes, it really can inflict unrecoverable financial losses, which would be comparable with the value of the purchased production equipment, installation and configuration costs, since such changes cause obsolescence of the purchased equipment making it almost unmarketable. When the enterprise does not expect such dramatic technological changes, but the planned output still decreases, the production equipment can be qualified as a liquid asset and sold to buyers who do need it to be working in other industries or international aircraft engineering corporations. However, we should note that due to the global decline (aviation industry worldwide) in demand for aviation products manufactured by a certain enterprise, the liquidity of the production equipment becomes low. Therefore, an excess stock of such equipment can be sold only with high discount.

Table 1 systematizes results of the analysis and evaluation of risks associated with investment projects intended to develop and upgrade the pool of resources and technologies in aircraft engineering enterprises.

Preliminary estimates and assessments may be subsequently specified over time in line with the project phase, when project parameters and respective investment in the phase change. Practical calculations should account for the uneven nature of investment cash flows, including specific phases of the investment project. However, even referring to simplified (qualitative) assessment (Table 1), we can see relative significance and importance of various risks that arise during investment projects pursuing the development and retrofitting of resources and technology in the aviation industry and some enterprises.

Drastic technological upgrades, new requirements to characteristics of advanced technologies and innovative production equipment during its purchase, installation, testing, commissioning and integration make respective risks the most significant and influential. Furthermore, additional costs and possible losses can reach the total value of the investment project before the production facilities are put into operation. In the last case scenario such costs will not exceed 85 percent of integral capital expenditures. At the phase of construction and mounting, the biggest losses may be incurred if the planned output is significantly reduced. However, in any case they will not exceed the value of the passive part of fixed assets used for production purposes, which account for 10-30 percent of integral capital expenditures incurred by most aviation enterprises. What causes the least important risk is changes in the product mix, with the level of aircraft engineering technologies remaining unchanged. In the other riskexposed situation, possible losses may not exceed 15-40 percent of the integral value of an investment project, even when all the phases are completed.

Therefore, the governance system of investment projects for improvement and retrofitting of the resource and technological pool of aviation enterprises shall envisage the most critical types of risks.

Based on the analysis, it is possible to flag the way to a better quality of innovative development management in aviation enterprises.

On the one hand, it raises no doubts that it is reasonable to manage an investment project for productive capacity construction in an adaptive manner. If any condition changes in the course of the project, it is adjusted for the new conditions. However, this idea needs to be clarified.

First, it is not always reasonable to respond to such changes in certain cases since the project is funded inter alia with unrecoverable investment. To alter the project in any way, the following aspects should be compared:

- additional costs needed to adapt the project to new conditions of corporate development;

- losses that will be incurred in case of zero changes.

Distinctions in the quality of optimal decisions can be identified by studying similar models [12]. However, it is noteworthy that although it seems useful and reasonable to adjust the project, the reasonableness of any alterations fades away as the completion date approaches. They often turn to be unprofitable. Drawing upon theoretical principles of the traditional 
options theory $[13,14]$, it should be kept in mind that not all options should be put in practice. Promising options should be realized only, since the holder's option constitutes the holder's right, rather than liability.

It is worth mentioning that conditions for the project implementation and managerial decision-making to analyze changes and adapt to them can change not only upon the emergence of new objects replenishing the existing pool of resources and technology in enterprises, i.e. during the period $t \in\left[t_{0} ; t_{0}+\tau\right]$, but also until the end of the final phase of the object life cycle. Productive capacities are also renewed/retrofitted/extended/converted/reduced/shut down/sold, etc. in manufacturing various types of products. What distinguishes pre-productive phases is that most of planned investment have not yet been made in them. That is why, project parameters may be altered at much lower expense to adjust the project while running the constructed and operational productive capacity.

Second, flexible management of investment project implementation consumes various resources. That is the reason why costs and possible gain from the adoption of the real options strategy shall be compared $[15,16]$. It is possible to evaluate the cost effectiveness of the adaptive management system for investment projects for improving and retrofitting the pool of resources and technologies in aviation enterprises by assessing the cost of real options, which can be adjusted through respective parameters of investment projects during various changes in predicted scenarios of their implementation.

Gains from adaptive management of projects for raising productive capacity of aviation enterprises can be quantified through estimated losses and costs proposed in this article and explained with the adaptation of innovative projects to various types of changes in project parameters as seen throughout its phases. To simplify the task, we assume conditions for a specific investment project change irrespective of its implementation process. Based on the assumption, time points of possible changes (expected demand and required product mix, cost of integrated production technologies and resources) can be considered to scatter evenly, meaning than there is equal probability that such changes may occur throughout the entire period of the investment project. Considering and applying the assumption about changing conditions, we can estimate expected costs and losses as a result of respective project adaptations. As we note above, it is necessary to accommodate the reasonableness and possibility of a flexible decision, which would depend on the project phase and volume of invested funds.

The effectiveness of flexible policy for management of the pool of resources and technologies in aviation enterprises can be evaluated (assessed) through time average of the highest possible gain for the entire life cycle of a changing project throughout the period of such changes. The project can be adjusted, if appropriate. However, if such adjustments have no sense already, they should be omitted. The average is formally embodied by integrating the time-realistic gain throughout the entire life cycle of the investment project, rather than at the phase of construction or modification of productive capacity. Afterwards the resultant integral indicators should be compared with identical integral functionality based on the assumption that no changes and adjustments of the innovative projects are not in progress. Resulting from the comparison of two estimated based on the proposed calculation methods, the estimate will reflect the effectiveness of each real option implying that parameters of projects for development and retrofitting of the pool of resources and technology in aviation enterprises can be changed. Indeed, possible changes in the project environment can have different frequency and amplitude. At different phases various changes result in various financial losses and additional costs. That is why the parameters will also require the smoothing.

Some methodological and theoretical issues arise since there are several types of risks we investigate in this article. If they are assumed to be unrelated, then the expected cost effectiveness of flexible management of investment projects is assessed as the sum of values of each option corresponding with changes in the product mix, integration of new production technologies and adjustment of the existing productive capacity. Further R\&D in this sector should refer to findings indicated hereinafter [17-19].

Following the analysis and technical and economic distinctions of the aviation industry at its current technological level, we demonstrate that the most serious and perilous exposures stem from risks associated with dramatic technological retrofitting, 
modified requirements to production equipment during its purchase, mounting, testing, commissioning and implementation. When a production facility is put into operation, additional costs and losses may be incurred. During the construction and mounting, a significant reduction in the production output may induce the highest losses, but in any way the losses will not exceed the value of the passive part of fixed assets employed in the production process. The least significant risk is associated with changes in the product mix, while the technological level of the aviation industry remains the same.

\section{Table 1}

Estimates of possible unrecoverable costs and losses in case of changes in the investment project by nature of changes and implementation stage

\begin{tabular}{|c|c|c|}
\hline Project phase & Construction and Mounting & $\begin{array}{l}\text { Purchase and installation of equipment, testing, } \\
\text { and commissioning }\end{array}$ \\
\hline Decline in demand for products & $\begin{array}{l}\text { Approximating the amount of investment } \\
\text { in excess capacity. } \\
\text { Total: } 10-30 \text { percent of value of excess } \\
\text { productive capacity }\end{array}$ & $\begin{array}{l}\text { Losses during the construction and mounting + cost of equipment } \\
\text { installation, testing and commissioning + losses relating to drop } \\
\text { value of dismantled equipment (they are significant during } \\
\text { the industry decline) + equipment dismantling costs. } \\
\text { Total: up to 30-40 percent of total value of excess productive } \\
\text { capacity }\end{array}$ \\
\hline $\begin{array}{l}\text { Changes in the product mix } \\
\text { (the technological level remaining } \\
\text { unchanged) }\end{array}$ & Additional costs are negligible & $\begin{array}{l}\text { Costs during the construction and mounting + costs about } 10-20 \\
\text { percent of initial cost of equipment, its mounting, testing and } \\
\text { commissioning. } \\
\text { Total: up to 7-15 percent of project value }\end{array}$ \\
\hline Changes in technology & $\begin{array}{l}\text { Additional costs of about } 30-50 \text { percent } \\
\text { of value of buildings, facilities } \\
\text { engineering utilities. } \\
\text { Total: } 5-15 \text { percent of project value }\end{array}$ & $\begin{array}{l}\text { Costs during the construction and mounting + costs commensurate } \\
\text { with financial expenditures for purchase and installation } \\
\text { of equipment (during dramatic technological changes), testing, } \\
\text { and commissioning } \\
\text { Total: } 70-85 \text { percent of total project value }\end{array}$ \\
\hline
\end{tabular}

\section{Source :Authoring}

\section{Figure 1}

Changes in the accumulated amount of investment

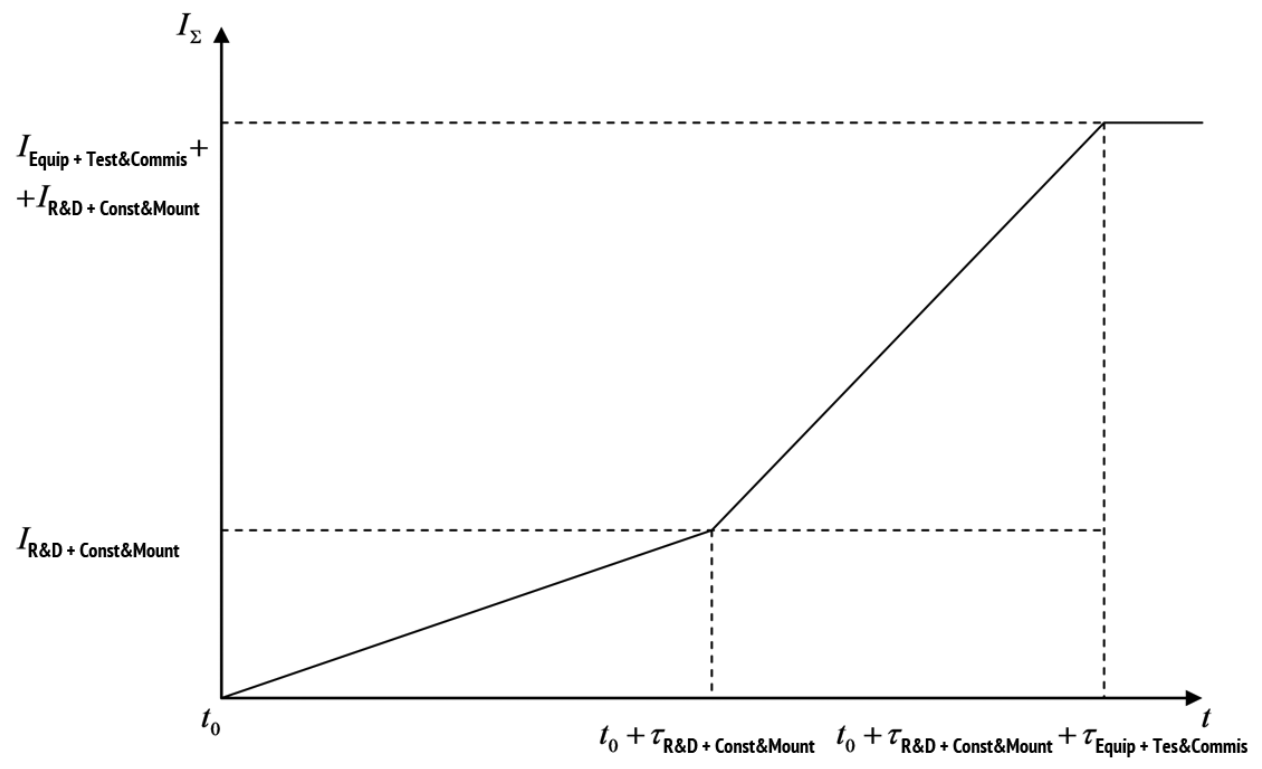

Source : Authoring

Please cite this article as: Bat'kovskii A.M., Klochkov V.V., Khrustalev E.Yu. Assessment of Investment Project Risks in Aviation. 


\section{Acknowledgments}

This article was supported by the Russian Foundation for Basic Research, grant № 16-06-00028-a.

\section{References}

1. Baev I.A., Alyabushev D.B. [Real options approach: From securities to innovation]. Vestnik UGTU-UPI. Seriya Ekonomika i upravlenie = Bulletin of Ural Federal University. Series Economic and Management, 2010, no. 3, pp. 52-62. (In Russ.)

2. Bukhvalov A.V. [Real options in management: An introduction]. Rossiiskii zhurnal menedzhmenta = Russian Management Journal, 2004, no. 1, pp. 3-32. (In Russ.)

3. Sokolova Yu.V. [Venture financing development: Forms of organizations, method of discrete financing]. Upravlenie ekonomicheskimi sistemami, 2012, no. 12. (In Russ.) URL: http://uecs.ru/uecs48-482012/item/1910-2012-12-26-12-31-42

4. Mishchenko A.V., Koshelev P.S. [Methods and models of operations management innovation project, taking into account the uncertainty and risk]. Audit i finansovyi analiz = Audit and Financial Analysis, 2014, no. 6, pp. 117-128. (In Russ.)

5. Baranov A.O., Myzyko E.I. [Real options in venture investment: Valuation from a venture fund position]. Vestnik NGU. Seriya Sotsial'no-ekonomicheskie nauki = Vestnik of Novosibirsk State University. Series: Social and Economic Sciences, vol. 11, iss. 2, pp. 62-70. (In Russ.)

6. Allen M., Carpenter C., Hutchins M., Jones G. Impact of Risk Management on Project Cost: An Industry Comparison. Journal of Information Technology \& Economic Development, 2015, vol. 6, iss. 2, pp. 1-19.

7. Bertoni F., Croce A., Guerini M. The Effectiveness of Public Venture Capital in Supporting the Investments of European Young High-Tech Companies. July 11, 2012. URL: http://dx.doi.org/10.2139/ssrn.2103702

8. Biancardi M., Villani G. Robust Monte Carlo Method for R\&D Real Options Valuation. Computational Economics, 2017, vol. 49, iss. 3, pp. 481-498. URL: http://dx.doi.org/10.1007/s10614-016-9578-z

9. McNeil A., Frey R., Embrechts P. Quantitative Risk Management. Princeton, N.J., Princeton University Press, 2015, 699 p.

10. Haimes Y. Risk Modeling, Assessment, and Management. Hoboken, N.J., John Wiley \& Sons, 2005,861 p.

11. Rusanova A.L., Klochkov V.V. [Efficiency analysis of Russian practice of financing high-tech industry's innovative projects (on the example of aircraft industry)]. Audit i finansovyi analiz = Audit and Financial Analysis, 2011, no. 5, pp. 57-61. (In Russ.)

12. Baibakova E.Yu., Klochkov V.V. [Analysis of interaction of suppliers and customers of high-tech products in network structures]. Ekonomicheskii analiz: teoriya i praktika = Economic Analysis: Theory and Practice, 2013, no. 43, pp. 26-39. URL: https://cyberleninka.ru/article/v/analiz-vzaimodeystviya-postavschikov-i-zakazchikovproduktsii-vysokih-tehnologiy-v-setevyh-strukturah (In Russ.)

13. Bat'kovskii M.A., Konovalova A.V., Fomina A.V. [Risk management in innovative development credit institutions, financing high-tech enterprises]. Voprosy radioelektroniki = Questions of Radio-electronics, 2016, no. 1, pp. 94-102. (In Russ.)

14. Marshall J.F., Bansal V.K. Finansovaya inzheneriya [Financial Engineering]. Moscow, INFRA-M Publ., 1998,784 p.

15. Harrison R. Crowdfunding and the Revitalisation of the Early Stage Risk Capital Market: Catalyst or Chimera? Venture Capital, 2013, vol. 15, no. 4, pp. 283-287. URL: http://dx.doi.org/10.1080/13691066.2013.852331

16. Kendrick T. Identifying and Managing Project Risk: Essential Tools for Failure - Proofing Your Project. New York, AMACON, 2015, 411 p. 
17. Mel'nikova E.F. [Resistance to changes in project management]. Ekonomicheskii analiz: teoriya i praktika= Economic Analysis: Theory and Practice, 2015, no. 29, pp. 61-68.

URL: https://cyberleninka.ru/article/v/korrektsionnaya-rezistentnost-v-upravlenii-proektami (In Russ.)

18. Savilov S.I. [Issues of considering the interval uncertainty in evaluating the efficiency of investment projects in Russia's non-stationary economy]. Natsional'nye interesy: prioritety $i$ bezopasnost' = National Interests: Priorities and Security, 2015, no. 30, pp. 38-47. URL: https://cyberleninka.ru/article/v/problemy-ucheta-intervalnoyneopredelennosti-pri-otsenke-effektivnosti-investitsionnyh-proektov-v-nestatsionarnoy-ekonomike-rossii (In Russ.)

19. Burenok V.M., Lavrinov G.A., Khrustalev E.Yu. Mekhanizmy upravleniya proizvodstvom produktsii voennogo naznacheniya [Military production management mechanisms]. Moscow, Nauka Publ., 2006, 303 p.

\section{Conflict-of-interest notification}

We, the authors of this article, bindingly and explicitly declare of the partial and total lack of actual or potential conflict of interest with any other third party whatsoever, which may arise as a result of the publication of this article. This statement relates to the study, data collection and interpretation, writing and preparation of the article, and the decision to submit the manuscript for publication. 